\title{
Wine and Health; it's a Story.
}

\section{Jean-Pierre Rifler}

Emergency physician, Nutritionist, Oenologist technician, Emergency department 21400 Châtillon-sur-Seine.

Corresponding Author: Jean-Pierre Rifler, Emergency physician, Nutritionist, Oenologist technician, Emergency department 21400 Châtillonsur-Seine, France E-mail: jprifler@hotmail.com

\section{Received date: January 29, 2019; Accepted date: February 09, 2019; Published date: February 14, 2019.}

Citation: Jean-Pierre Rifler, Wine and Health; it's a Story. Jr. Nutrition and Food Processing. Doi: 10.31579/ 2637-8914 /023.

Copyright: @ 2019 Jean-Pierre Rifler. This is an open-access article distributed under the terms of The Creative Commons Attribution License, which permits unrestricted use, distribution, and reproduction in any medium, provided the original author and source are credited.

\section{Introduction}

Wine is the fruit of the vineyard and the work of man.

Since the highest antiquity, wine has been an important element of ritual and sacrificial practices. In Greece, he was both a cult object anda symbol of culture.

The Mysteries celebrated in honor of Dionysus gave birth to the theater. Rome had more conflicting relations with Bacchus, God of Wine, and the Bacchanalia.

This religious ceremony, which turned into an orgy, was then forbidden.But the sacralization of wine, the blood of God, only happens through Christianity.

This had not been the case in the Jewish religion where it remains an object of sacrifice and blessing, neither among Muslims, where it is both an object of repulsion on earth and the supreme reward in paradise.

\section{Key words}

wine, mediterranean diet, health, alcohol, polyphenols, hormesis, cardiovascular protection.

\section{The pagan wine}

1. The earliest traces of viticulture date back to $6000 \mathrm{BC}$ and focus on the Mediterranean, grape growing, grape processing into wine is rooted in the border between Turkey and Armenia, near Mount Ararat. This is where Noah planted the first vines after the flood.

2. Wine, an exceptional drink, has given rise to a whole symbolism. It is linked to the vine which, after having given an abundant harvest, pledge of happiness, seems to die in winter to be reborn in the spring. A symbol of resurrection and eternal life, the wineit produces can be at once beneficent, drunk at low doses and become dreadfully drunk with excess.

3. Libation is a religious ritual consisting of the presentation of a drink, usually wine, as an offering to a god, by spilling a few drops on the ground or on an altar. This form of sacrifice was very practiced in all the religions of antiquity.

4. All cultures had their gods or goddesses, witnesses of this resurrection and the quest for eternity that only drunkenness could satisfy.

5. On the occasion of Dionysies, the first tragedies were performed in Athens. During the Dionysies all the activities of the city stopped, and the citizens were all invited to collaborate in the event. Such was the necessity of social cohesion; legal proceedings were interrupted while prisoners were temporarily released to participate in the festivities.

Bacchanalia were religious festivals, related to the Dionysian mysteries, they stood in honor of Dionysus-Bacchus, god of wine, drunkenness and overflowing, including sexual. Inspired by ancient Greek Dionysian festivals, Bacchanal ceremonies were introduced in Italy around $300 \mathrm{BC}$.
They soon served as a pretext for the most extravagant disorders because they evolved into nocturnal orgiastic festivals more and more frequent, which often had a bad reputation, because of public drunkenness and the sexual licenses they provoked.

In the ancient Greeks, it was customary to mix the wine with water during the banquet, as part of the symposion's good table manners.

In the second part of the banquet (the symposion), the assembly elects a symposiarque or "king of the banquet", in charge of determining the dosage of the mixture wine-water to realize as well as the number of cuts which will be drunk. The use of cutting water wine will continue in Rome and later in France and Italy.

The path of political virtue goes through wine, according to Plato. As the Athenian philosopher explains in his Laws, the use of wine is a necessary condition for the practice and civic celebration of virtue. United citizens are citizens who sing and dance together to rejoice at belonging to the same city.

This, only wine allows, because it disinhibits at the same time as it socializes. He is the condition of a successful social life.

\section{The divine wine}

In the Bible, wine and wine are cited 443 times.

If, from Genesis, the wine is hailed as "the blood of the vine", it is nonetheless a dreadful drink. Adam and Eve are banished from paradise for having tasted the forbidden fruit. God had allowed everything to Adam except the consumption of the fruit of the knowledge of good and evil, fruit that could be the grape, as on these columns marquees of the basilica of Vézelay (figure 1) or Mont Saint Michel (figure 2).

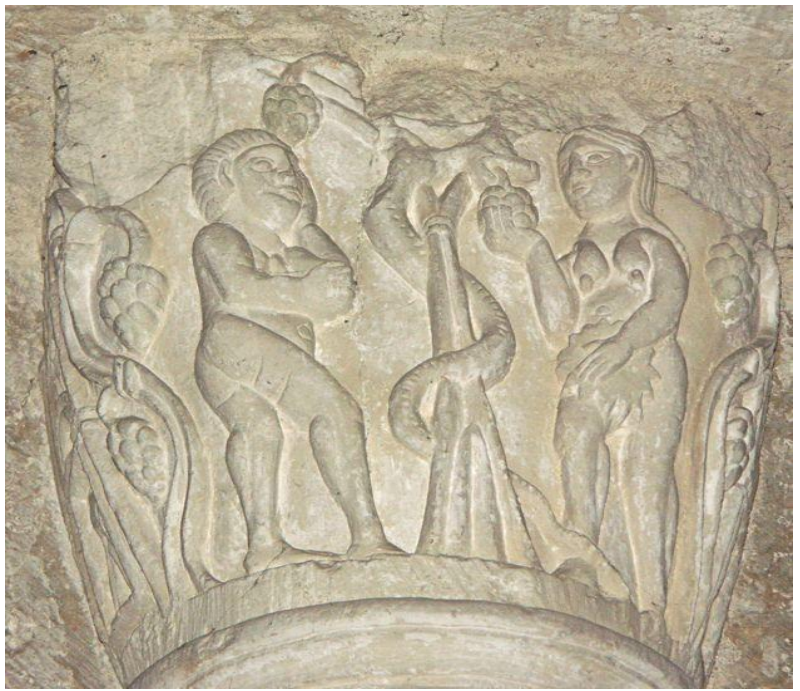


Figure 1. Column marquee of the basilica of Vezelay. 


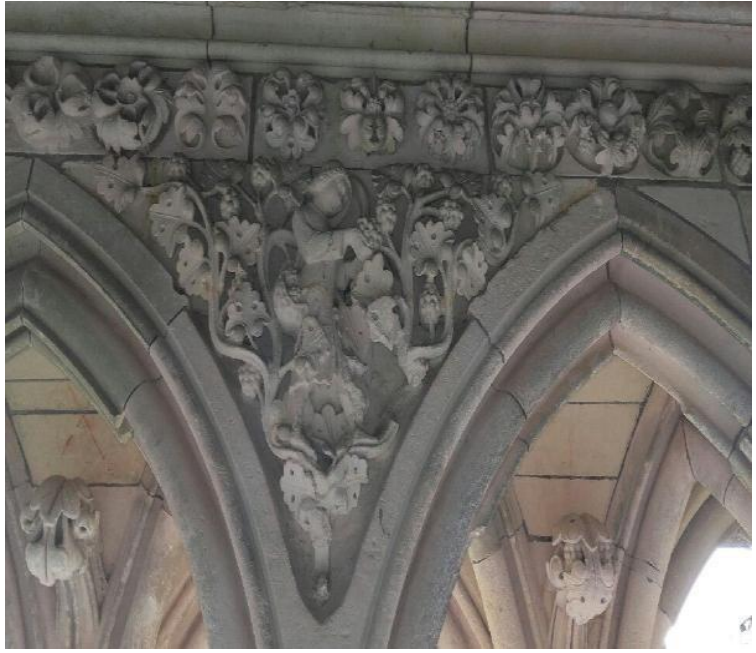

Figure 2. Column marquee of the "Merveille" in Mont Saint Michel.

The Book of Proverbs is there to remind: "The wine moderately drunk is the joy of the heart and the soul", "The wine drunk to the drunkenness discovers the heart of the superb", "The wine drunk with sobriety is a second life "," Wine drunk with excess is the bitterness of the soul ". For no one can forget that Lot, drunk, committed incest with his daughters and that Noah's drunkenness made him discover hisnakedness before his sons.

Some apocryphal texts explain that the fall of the patriarch was due to the intervention of Lucifer, the fallen angel. Very naively, Noah would have accepted his help to plant his vineyard after the Flood.

The latter, according to tradition, began by making a sacrifice by immolating a sheep, a lion, a monkey and a pig.

Following the drunkenness of the patriarch, Satan then explained: "At the first glass of wine, the man will become meek and humble like a sheep, at the second he will feel strong like a lion and will not stop boasting about it, third he will imitate the monkey, dancing while saying foolishness, the fourth, he will wallow like a pig in the mud andfilth.

For Christians, it will take the coming of Christ to erase the drunkenness of the first patriarch of humanity. Jesus of Nazareth presented himself by saying to his disciples: "I am the true vine andmy Father is the vine grower" and he continued "I am the vine and youare the branches".

\section{Judaism}

Wine plays a big role in halakha, Jewish laws and traditions. Kiddush is a blessing recited on the wine to be sanctified for Shabbat.

In the Tabernacle and in the Temple of Jerusalem, the libation of wine participated in the sacrificial function. But it should be noted that it is forbidden for priests to consume wine or other fermented beverages when they come to the tent of the rendezvous.

For the Hebrews the wine remained a natural and daily drink. Ablessing on wine is said before drinking.

Baruch atah Hashem (Adonai) elokeinu melech ha-olam, boray p'ri hagafen, "Praised be the Lord, our God, King of the universe, creatorof the fruit of the vine ". The sacred texts, from Moses, make such allusions that not drinking wine provoked stupor and indignation; an abstem could be suspected of being under the influence of the demon.

\section{Christianity}

The vine and the wine are very present in the Gospels.

If the role of the gods of antiquity was to bring the wine to the men, the appearance of the Christianity will modify the role of the wine which consequently becomes the blood of the Christ.

The wedding of Cana is a story from the New Testament. In theGospel according to John, the miracle of the change from water to wine is presented as the first of Jesus (figure 3).

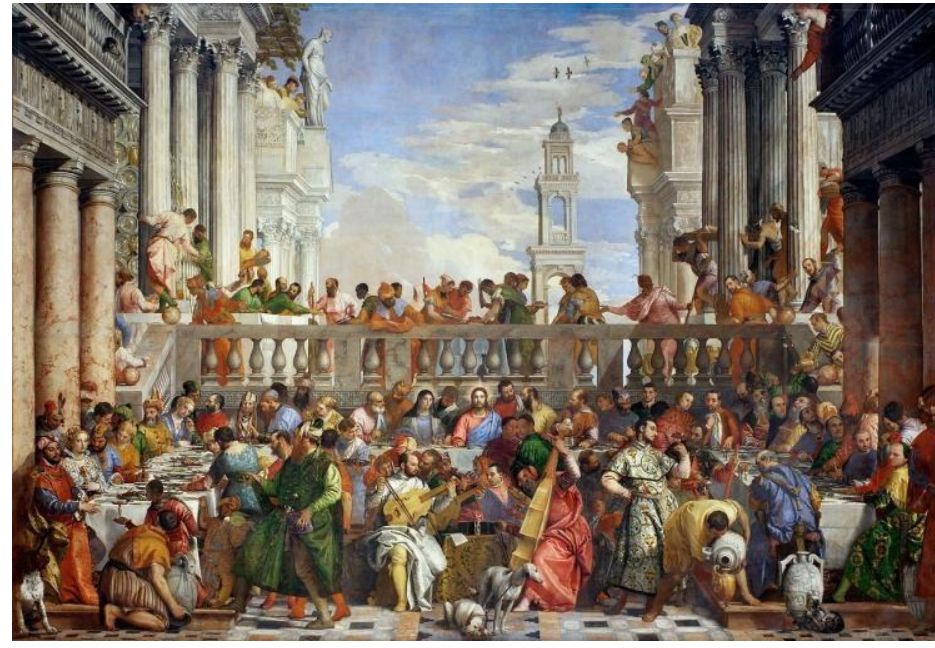

Figure 3. The Wedding Feast at Cana (1563), Paolo Veronese. Musée du Louvre.

It is, however, in the Last Supper that the symbolism of wine reaches its climax, to be assimilated to the blood of Christ. Mass and communion for all Christians are a reminder of the Last Supper where Jesus of Nazareth dedicated bread and wine.

It was a long journey to replace the ancient divinities with the holy protectors of the vineyard. Masses at Bacchus were still celebrated in 1348 to combat the Black Death. Saint Vincent did not prevail until the 13th century.

The culture of the vineyard had followed the paths of evangelization. Because wine was indispensable during communion. Until the twelfth century, the Benedictines planted the vine in Europe. In addition to the monastic needs were added those of the inns.

The Benedictine rule (1) was written, according to tradition, by Benedict of Nursia from 534. It was adopted and divulged following the creation of the order of Cîteaux, in 1098, by Etienne de Harding. Bernard de Clairvaux will largely contribute to spreading this rule which served as a model to that which he gave to the Poor Children of Christ who became Knights Templars.

\section{We will only mention rule $\mathbf{4 0}$}

\section{Measuring The Beverage}

1. Everyone "has received from God his particular gift: one this one, the other that one."

2. So we have some scruples to regulate the feeding of others.

However, considering the temperament of the weak, we think that a "hemin" [27 cl], (tableau 1, figure 4) of wine a day is enough for everyone.

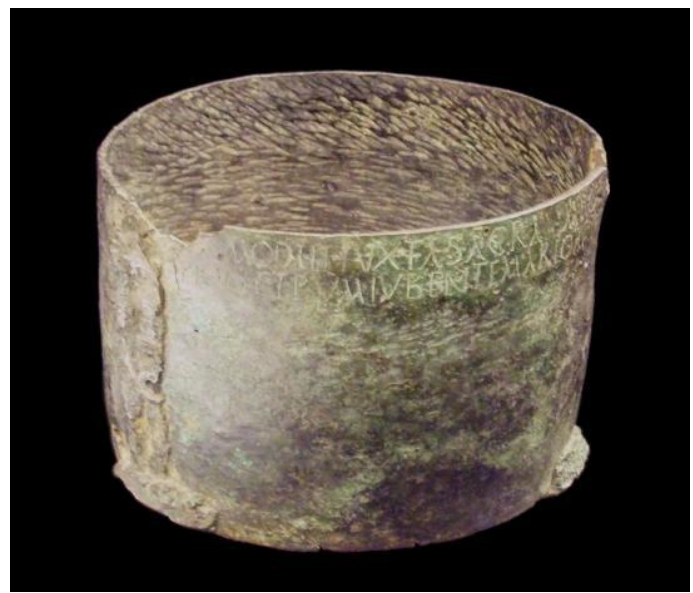

Figure 4. 'Modius of Ponte Punide', at the National Archaeological Museum of Spain (Madrid). Bronze Roman measurement container from the 4th centuryCE,foundin1913inSpain. 
Those to whom God gives grace to abstain, will know that they will receive a special grace. If the situation of the place, or the work, or the ardor of the summer, demands more, the superior will decide it; but he will take care in everything that one does not fall into satiety or intoxication.

6. We read, it is true, that the wine is not suitable for monks. But as we can not persuade the monks of our time, let us at least not drinkuntil satiety, but with sobriety:
7.Because "wine makes apostatize even the wise."

8. If the poverty of the place is such that this measure of wine can not be obtained, but much less or nothing at all, those who remain there will bless God and do not complain .

his is the warning we give above all: they abstain from murmuring.

\begin{tabular}{|l|l|l|l|l|}
\hline Roman unit & Equal to & Metric & Imperial & US fluid \\
\hline ligula & $1 / 288$ congius & $11.4 \mathrm{ml}$ & $0.401 \mathrm{fl} \mathrm{oz}$ & $0.385 \mathrm{fl} \mathrm{oz}$ \\
\hline cyathus & $1 / 72$ congius & $45 \mathrm{ml}$ & $1.58 \mathrm{fl} \mathrm{oz}$ & $1.52 \mathrm{fl} \mathrm{oz}$ \\
\hline acetabulum & $1 / 48$ congius & $68 \mathrm{ml}$ & $2.39 \mathrm{fl} \mathrm{oz}$ & $2.30 \mathrm{fl} \mathrm{oz}$ \\
\hline quartarius & $1 / 24$ congius & $136 \mathrm{ml}$ & $4.79 \mathrm{fl} \mathrm{oz}$ & $4.61 \mathrm{fl} \mathrm{oz}$ \\
\hline hemina or cotyla & $1 / 12$ congius & $273 \mathrm{ml}$ & $\begin{array}{l}9.61 \mathrm{fl} \mathrm{oz} \\
19.22 \mathrm{fl} \mathrm{oz}\end{array}$ & $0.961 \mathrm{pt}$ \\
\hline sextarius & $1 / 12$ congius & $546 \mathrm{ml}$ & $1.153 \mathrm{pt}$ \\
\hline congius & $\mathbf{1}$ congius & & 0.75 & $0.719 \mathrm{gal}$ \\
\hline urna & 4 congii & 3.271 & $2.88 \mathrm{gal}$ & $3.46 \mathrm{gal}$ \\
\hline amphora quadrantal & 8 congii & 13.11 & $5.76 \mathrm{gal}$ & $6.92 \mathrm{gal}$ \\
\hline culeus & 160 congii & 26.21 & $115.3 \mathrm{gal}$ & $138.4 \mathrm{gal}$ \\
\hline
\end{tabular}

Table 1.Ancient Roman liquid measures. (2)

sanctified wine, to be a Muslim is to forbid it.

Until the end of the eighteenth, Christians consume alcohol on a daily basis, and use almost only wine (fermented grape juice) during the central rite, the Eucharist, which is the last meal of Christ. According to the Bible and Christian traditions, alcohol is a gift from God that makes life happier and its consumption can even be good for your health.

Paul tells his disciple Timothy: "Stop drinking only water, but take a little wine to help your digestion, since you are often sick."

The only abuse that leads to drunkenness is a sin.

\section{Quran}

In this sacred text that Muhammad proposed as a rule of life to his disciples, from 610, only five surah mention wine (khamr) or vine (nab). Only one reports a ban in a broad setting.

Wine is proscribed to believers as well as games of chance and divining stones:

"O you who believe, know that wine, games of chance, standing stones and divining arrows are an abomination and a work of the devil. Avoid them. Perhaps you will be blessed "(Surah V, 30).

Two others note that wine can be great good and bad. But the latter is often superior to good: "They ask you about wine and games of chance; tell them that they both have a lot of dirt, but also good for men. Yet their deeds are greater than their benefits "(Surah II, 219).

"And from the fruits of palm trees and vines, you will draw an intoxicating drink and a great good. In this there are signs for a people who thinks "(Surah XVI, 67).

The last two suras dealing with wine make it one of the paradise delights promised by the Prophet:

"In the image of paradise, which was promised to the faithful, and where rivers of incorruptible water flow, rivers of unalterable milk, rivers of exquisite wines" (Surah XLVII, 15).

"The pure shall be watered with a rare wine" (Surah LXXXIII, 25).

The wine was initially completely forbidden, but the Abbasid caliphs rehabilitated the wine. This dynasty of Sunni Arab caliphs ruled the Muslim world from 750 to 1258 . The place of wine is the church. Fundamental element of the Eucharist, it is the blood of Christ. From the moment, after the Crusades especially, where the Islamic power wants to clearly distinguish Islam from Christianity, how to do for Muslims who go to church? If we do not separate places of worship, at least we must distinguish rituals. If being a Christian is to drink the 
It is by distinction from Christians that Muslims should not drink wine, because to drink wine is to do Mass. To forbid wine is to forbid these syncretic Muslims from participating in mass.

Note that the Koran makes no mention of Noah's drunkenness. Many Muslim philosophers have extolled the benefits of wine.

\section{The wine doctor}

The earliest records of a therapeutic and medicinal use of wine date backto 3150 years before $\mathrm{J}-\mathrm{C}$, the analysis of an earthen jar showed residues that correspond to the descriptions of the remedies described in the medical papyri.

It is with Hippocrates (460-377 BC), the father of the modern medicine, that the wine knows a true consecration in the field of the therapy.

He already said: "Wine is a thing wonderfully appropriate to man if, in health as in sickness, it is administered appropriately and justly, according to the individual constitution."

A little later, Theophrastus (372-287 BC), an expert botanist, invents medicinal wines in his "history of plants" by mixing herbs and spices.

Dioscoride (20-90 AD), Greek doctor, wrote "de materia medica", describing the medicinal use of more than 800 substances, which will serve as a basis of pharmacological knowledge, and his copies in all languages were used until early 16 th century.

Pliny the elder, born in $23 \mathrm{AD}$, died in 79 during the eruption of Vesuvius, he advocated in his "natural history", medicinal applications of wine but also of vines, grape leaves and grape seeds. He confirmed the teachings ofHippocrates: "wine alone is a remedy; it nourishes the blood of man, gladden the stomach and amortize sorrows and worries. ". In Pompei, the wine merchants displayed a caduceus on their point of sale, half tavern, half pharmacy.

Galen of Pergamum (129-216 AD), is considered with Hippocrates as one of the main founders of the bases of medicine. Galen's medical theory dominated medicine until the 18th century. When he was a gladiatordoctor in Rome, he treated wounds with "cloths soaked in black and pungent wine." He proposes a recipe for theriac, a pharmaceutical preparation that included more than 70 ingredients, including wine, which served as a panacea.

With the fall of the Roman Empire, the works of ancient doctors are temporarily forgotten. But the monks continue the cultivation of the vine and tend with the wine. 
Since the end of the Great War, wine has been considered a factor of

In the 9th century, the conviction of the therapeutic virtues of wine is again accepted. Constantin the African (1020-1087) from 1080 translates into Latin Arabic texts, themselves derived from GrecoRoman knowledge. And the dissemination of knowledge is needed from Salerno.

On the front door of the Salerno Hospital in Italy, it is engraved: "Drink a little wine." The books of this prestigious Faculty of Medicine detail the principles: "Good wine gives old people a new lease of life, pure wine has multiple benefits, it tones the brain, makes the stomach jubilant, hunt bad moods. It makes the mind sharp, the eyes bright, the ear thin, dispenses with being overweight and gives a robust health in life. "And to the masters of this faculty to add in addition this judicious advice which has not lost any of its value: "... drink a little, but that it is good."

Avicenna, Ibn Sina, (980-1037), a Persian physician, having translated the works of Hippocrates and Galen, compiled his knowledge into his "canon of medicine". Avicenne is interested in ways to maintain health, he recommends the practice of sport and hydrotherapy. He prevented suppuration by the application of compresses dipped in old red wine strongly alcoholic. Persian in her time had such a passion for wine that even the Muslim religion did not succeed in suppressing it.In the book $\mathrm{V}$ of the Canon, one can read a chapter on the therapeutic use of wine. As a faithful galenist, Avicenne sells the virtues of wine ("he strengthens the viscera, etc."), notes that "the wine does not easilydrunk a person with a solid head," indicates who should drink what type of wine, how consume it during the meal and note that "as you know, old wine is like a medicine". As a good doctor, he warns against the dangers of intoxication in case of excessive consumption but provides some advice against hangovers.

The wine book, written around 1322 and attributed to the Catalan doctor Arnaud de Villeneuve (1240-1311) who professed at the University of Montpellier is a collection of recipes of medicinal wines, which takes up the ancient Greek-Latin pharmacological tradition. Wine is already considered as a therapeutic agent. The treaty quotes Galen and Avicenna abundantly. The principle of wine cut with water is recalled "46. Wine with water. The wine with water is very healthy, although it is not the best for the sick ... The heat and dryness of the wine are thwarted by the coldness and moisture of the water. And these are changed in turn. The result is a temperate product whose preparation requires precaution ... "(De vinis p.144)

"Wine is wonderful for the melancholy, the angry and the heart, for those who have problems with the liver, the bladder, the circulation and especially the arteries. The wine heals from depression, it brings joy by bringing man back to reason and calms the heartbeat. It relievesa sudden rise in temperature and even prolonged fever. To those who make use of it, it gives a reasonable attitude of the soul and it makes them rejuvenate by the will of God "

Rabelais (1483-1553), a physician trained in Montpellier, proclaimed "the juice of the vine clarifies the spirit and the understanding, chases sadness, and gives joy and joy".

Bordelais Montaigne (1533-1592) will say that he is so accustomed to the mixture that "neither can I drink pure water or pure wine".

In France, ordinary water wines will be cut until the middle of the twentieth century.

Pasteur (1822-1895) in his famous work published in 1866 considered wine as "the healthiest and most hygienic beverage".

Phylloxera, a terebrant insect, inadvertently imported from the United States in the years 1865-70, will plunge viticulture into its first major crisis. The decimated European vineyard is fortunately saved by the importation of American plants resistant to the insect. French production is falling and it is the southern vineyards that are benefiting from it, by placing lower quality wines on the market.

As early as October 1914, the warned stewardship of a predictable, long-lasting war, to improve life in the trenches, added to the ordinary troops a ration of wine.

In 1915, the National Academy of Medicine defined wine consumption standards around 50 to 75 centilitres per meal.

The war over, many anti-alcoholic campaigns developed, mixing wine and alcohol.

The teachers, in their moral classes, sensitized their pupils to the plague of alcoholism. To counterbalance these claims, Pasteur's ideas on the benefits of wine were disseminated.

In 1991, the EVIN law, and its fatwa against alcohol, questioned everything, the anti- alcoholic leagues wanting to govern individual freedoms in the name of public health, amalgamating pell-mell wine and other alcohols.

Recently, many studies have tried to unmask the "French Paradox", a term used by Serge Renaud in 1991 on CBS, this French paradox consisting in a low mortality of cardiovascular origin despite a high consumption of saturated fats (3).

Epidemiological studies of Saint Leger (4) then of Keys (5) (13000 subjects followed for 20 years, beginning of the study in 1952) showed that the Mediterranean basin, and more particularly Crete, was protected, probably because of a specific diet.

The MONICA project (6) confirmed the particular position of France, and showed a south- north mortality gradient confirming this probable originof the very different diet between Toulouse and Lille. The intake of mono and poly-unsaturated fats, garlic, duck fat, low-fat diet, high intake offruits and vegetables, have been advanced to identify the Mediterranean diet, the Cretan diet is characterized by his frugality. All these Mediterranean civilizations are also wine civilizations and some wanted tosee an important or even indispensable element of this protective diet against cardiovascular diseases.

The antioxidant effect of red wine flavonoids seems to be one of the mechanisms of vascular protection provided by the Mediterranean diet.

We know from Yusuf's meta-analysis (7) that moderate alcohol consumption (two drinks a day) is a cardiovascular protective factor, as is the decrease in LDL, smoking cessation, fruits and vegetables and that physical activity.

Atheroma plaque in the coronary arteries is responsible for myocardial infarction and at carotid level it causes ischemic stroke.

The mechanism of plaque formation is complex and multifactorial, but always begins with an accumulation of LDL that oxidizes in the intima of the artery.

The effect of red wine on the oxidation of LDL could be the key to French Paradox.

Indeed, the decrease of LDL (the bad cholesterol) and the increase of the antioxidant power of the serum are two major protective factors. If there is less LDL and they are less oxidized, they will deposit less in the arteries, so the formation of atheroma plaque will be delayed.

The interstroke study (8) confirms these data for stroke at doses of one drink per day.

Some will make the short cut by saying that a glass for the brain and two for the heart is good the three glasses allowed a day since Saint Benedict.

But before recommending red wine as a beneficial dietary adjunct, it should be noted that the dose of alcohol must remain minimal so as not to cause the known deleterious effects of ethanol.

On the other hand, it is certain that, whatever the red wine, it is a soup of antioxidants that can be preserved for a very long time when vinification is carried out in a traditional way (control of temperatures, long maceration, aging in barrels new), which is easily assimilated by the body because of the alcohol (9).

Alcohol provides superior bioavailability. It is not by chance that wine has always been part of the food ration of Mediterranean countries, it was the only way to conserve antioxidants (plants) for the winter (figure 5). 


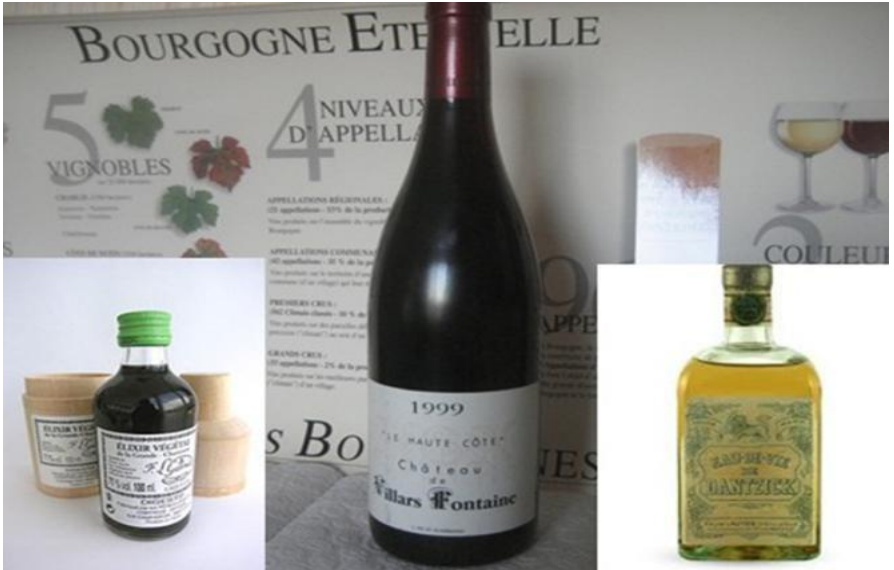

Figure 5. Red wine is an elixir of life.

At the time of globalization, apertisation and freezing, we still have the fact that a glass of red wine brings many more antioxidants easily assimilated than large quantities of fruits and vegetables. (A glass of wine brings the same antioxidant effect as 20 liters of tea).

The J curve (figure 6) represents the total mortality compared to the number of glass of wine drink per day. In the version of Ellison (10), ischemic heart disease is isolated from other causes of mortality, if we notice an increase in deaths from accidents, cancer or sudden death for daily consumption greater than 3 glasses, it is necessary to note an increase of cardiovascular protection activity beyond these doses.

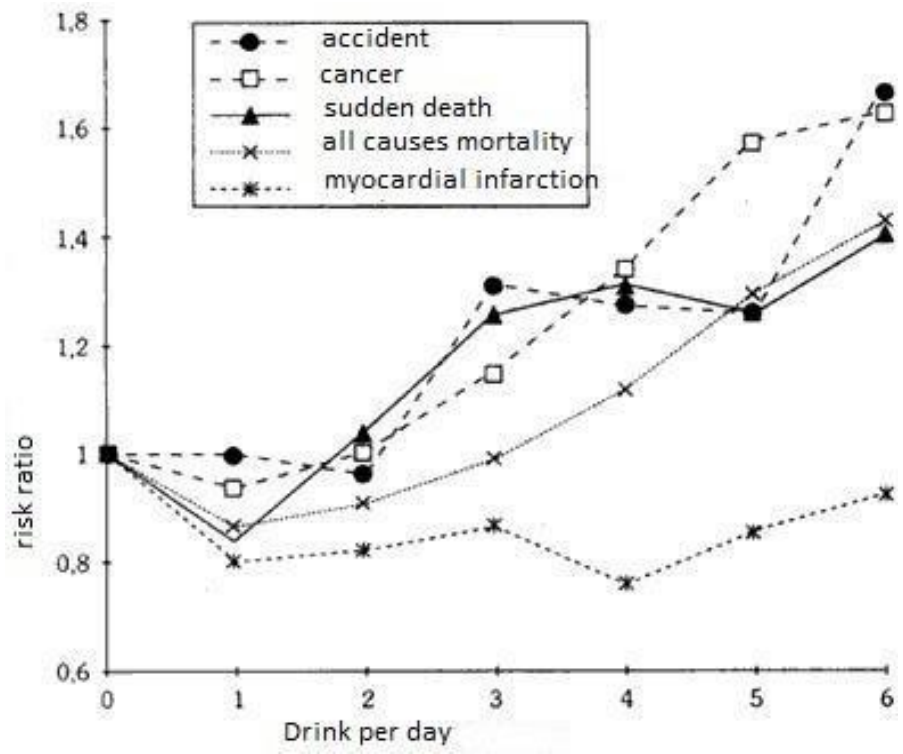

Figure 6. The J curve

On the other hand a study of 1997, showed that it is the regular consumption of moderate doses of wine $(200 \mathrm{ml})$ which allows an antioxidant protection. In another 2006 study, a supplement of $200 \mathrm{ml}$ of red wine, during the midday meal, of healthy volunteers, showed a decrease in total cholesterol and LDL cholesterol in just one week (Rifler and Blache, 11). This regular and moderate consumption of red wine thus makes it possible to counteract the initiating factors of the atheromatous plaque, and therefore have a cardiac protective effect in primary prevention.

In secondary prevention, we demonstrated in 2012 (12,13), the same phenomenon on patients with myocardial infarction, 3 days after the accident, a cautious European regime was set up, a group drinking water, the other group drinking wine ( 2 glasses a day). The wine group shows the same benefit as in primary prevention.

And especially the moderate dose wine brings pleasure, pleasure of an exchange between guests around a good meal. It is no coincidence that the gastronomic meal of the French was included in UNESCO's universal heritage in 2010.
At a moderate dose, wine is the best of anxiolytics; allowing citizens to relax with a glass of wine, rather than making them feel guilty, would reduce prescription of benzodiazepines and antidepressants and reduce thesocial security gap while eliminating the side effects of these dangerous drugs.

Only misuse, abuse, is dangerous.

Sometimes adulated, sometimes demonized, it is certain that the tasting ritual is important. Symposion for the Romans, French meal supported by Unesco. Everything goes through education.

In conclusion, let's drink fewer, but drink better, to live older.

\section{References}

1. La règle de saint Benoit, Tomes I et II, introd., trad. et notes par Adalbert de Voguié, texte établi et présenté par Jean Neufville, collection Sources chrétiennes, 181 et 182, Éd. du Cerf, 1972.

2. Smith, Sir William; Charles Anthon (1851) A new classicaldictionary of Greek and Roman biography, mythology, and geography partly based upon the Dictionary of Greek and Roman biography and mythology New York: Harper \& Bros. Tables, 1024- 1030

3. Renaud S., de Lorgeril M. «Wine, alcohol, platelets, and the French paradox for coronary heart disease, Lancet, (339)1992 1523-1526.

4. St Leger A. S., Cochrane A. L., Moore F. « Factors associated with cardiac mortality in developed countries with particular reference to the consumption of wine », Lancet, 1,1979), 1017-1020.

5. Keys A (Ed). « Coronary heart disease in seven countries. Circulation 1970;41(Suppl.1):211 pp

6. Tunstall-Pedoe H., Kuulasmaa K., Amouyel P., Arveiler D., Rajakangas A. M., et al( 1994),Myocardial infarction and coronary deaths in the World Health Organization MONICA Project. Registration procedures, event rates, and case-fatality rates in 38 populations from 21 countries in four continents ». Circulation, (90), 583-612

7. Yusuf S., Hawken S., Ounpuu S., Dans T., Avezum A et al (2004) Effect of potentially modifiable risk factors associated myocardial infarction in 52 countries (the INTERHEART study): case-control study Lancet, (364), 937-952.

8. O'Donnell M. J., Xavier D., Liu L., Zhang H., Chin S. L, et al (2010) Risk factors for ischemic and intracerebral haemorrhagic stroke in 22 countries (the INTERSTROKE study): A case-control study The Lancet, vol. 376 112-123.

9. Miyagi Y., Miwa K. Inoue H. ( 1997) Inhibition of human low- density lipoprotein oxidation by flavonoids in red wine and grape juice, American Journal of Cardiology, vol. 80, 1627-1631.

10. RCurtis Ellison., Cheers Epidemiology . (1990) 1 (5) 337-33

11. Colloque Vin et Nutrition. Orateurs: B. Hudelot, Y. Cottin, D( 2008). 23-25.

12. Rifler J.-P., Lorcerie F., Durand P., Delmas D., Ragot K., et al (2012) A moderate red wine intake improves blood lipid parameters and erythrocytes membrane fluidity in post myocardial infarct patients , Molecular Nutrition \& Food Research,. (56)345- 351.

13. Rifler J.-P., Latruffe N. « Moderate Red Wine intake in Secondary Prevention for patients with cardiovascular disease ", Congrès Vitagora, 20-21 mars 2013, Dijon, France. 